\title{
A review of the effect of integrated STEM or STEAM (science, technology, engineering, arts, and mathematics) education in South Korea
}

Nam-Hwa Kang(D

Correspondence: nama.kang@knue. ac.kr

Department of Physics Education, Korea National University of Education, Cheongju, Republic of Korea

\begin{abstract}
Integrated STEAM education in South Korea is an approach to preparing a quality STEM workforce and literate citizens for highly technology-based society. Through a literature review, this study examined the STEAM education initiative in South Korea and investigated its effects on learning and teaching. Studies in South Korea found that teacher professional development courses increased teachers' recognition of the initiative as well as their confidence in teaching STEAM. Teacher interviews showed that coaching in classroom practices within teachers' professional development was helpful. Although studies reported that many science teachers adopted STEAM in science teaching, there was a lack of research on how teachers taught STEAM lessons, let alone the connections between teachers' perceptions of STEAM and their classroom practices. As for STEAM effects on student learning, a number of meta-analyses showed that students' experiences with STEAM were effective in both cognitive and affective learning. The effect was higher in affective domains. Interviews with college students who had STEAM experiences in grade school showed that the effects could be long-term. The metaanalysis studies failed to identify significant mediating factors, which required further indepth research on how contextual variables function in student learning. This paper provides a glimpse of what can be achieved through STEAM efforts, and what should be further researched for better theory and practice.
\end{abstract}

Keywords: Integrated STEM, STEAM, STEAM pedagogies, STEM pedagogies, STEAM effects

\section{Introduction}

Understanding science and mathematics knowledge and practices, as well as technological and engineering practices, has become a priority for national education programs across the world (Kelley \& Knowles, 2016). The United States Next Generation Science Standards (NGSS) includes engineering design and practices as primary elements of science education (NGSS Lead States, 2013). The UK has also put forth educational policy agenda promoting science, technology, engineering, and mathematics (STEM) integration both in and out of schools (STEM Learning, 2018). Germany also created a national STEM forum to promote STEM education for all levels of education, formal and informal (Nationales MINT (STEM) Forum, 2014). Similarly, the

(c) The Author(s). 2019 Open Access This article is distributed under the terms of the Creative Commons Attribution 4.0 International License (http://creativecommons.org/licenses/by/4.0/), which permits unrestricted use, distribution, and reproduction in any medium provided you give appropriate credit to the original author(s) and the source, provide a link to the Creative Commons license, and indicate if changes were made. 
Ministry of Education in South Korea issued a nation-wide policy agenda in 2011, which included the promotion of integrating science, technology, engineering, arts, and mathematics education (STEAM hereafter). All these efforts in developed countries to reform STEM education are to meet the challenges of the twenty-first century which require strengthening the workforce in STEM areas to address global issues and STEM literacy for a new era (Kelley \& Knowles, 2016).

Integrated STEAM education in South Korea is an approach to preparing a quality STEM workforce and literate citizens for highly technology-based society by integrating science, technology, engineering, arts and mathematics in education. It is named differently from STEM due to its emphasis on arts (fine arts, language arts, liberal arts, and physical arts) as an important component of integration. While the STEAM reform movement is in alignment with STEM reform in other countries, its added component, i.e., arts, was inspired by the concurrent social discourse on education for creativity and a well-rounded citizen in the twenty-first century (Baik et al., 2012). Also, the national concern for students' low confidence and interest in learning science regardless of high achievement (Organization for Economic Co-operation and Development, 2013) factored in promoting the integration of arts with STEM education for affective goals. A similar idea now can be found elsewhere (e.g., Henriksen, 2014; The STEAM journal, 2013). Since then, the South Korean government has allocated a substantial educational budget for promoting STEAM through various routes. With the idea of creating innovative thinkers by integrating ideas from STEAM fields, i.e., all subjects in schools, the term, 'convergence education' has been coined and used to refer to the integrated STEAM education initiative. Convergence refers to creating new ideas or products formed by interdisciplinary or multidisciplinary thinking. Thus, the main goal of integrated STEAM education is to develop 'talents in convergence'.

This study examined STEAM education initiatives in South Korea and investigated their effects on learning and teaching. In doing so, we gain insight into future directions of STEAM or STEM education research and practices.

\section{Integrated STEM education in the literature}

Because South Korean STEAM education is informed by and aligned with STEM initiatives in other countries, a review of STEM education in international literature would provide a context for understanding STEAM education in South Korea. Based on a growing need for literate citizens in a highly technological society, and an increasing national need for a STEM workforce, a recent curricular reform movement calls for an integrated approach to teaching science and mathematics in which technology and engineering provide methods and contexts of learning (National Academy of Engineering and National Research Council, 2014). For example, Bybee (2010) calls for quality science education that includes technology and engineering:

A true STEM education should increase students' understanding of how things work and improve their use of technologies. STEM education should also introduce more engineering during precollege education. Engineering is directly involved in problem solving and innovation, two themes with high priorities on every nation's agenda.... the creation of high-quality, integrated instruction and materials, as well as the placement of problems associated with grand challenges of society at the center of study. (p. 996). 
Whereas there have been initiatives for integrated STEM education in a number of developed countries including South Korea, the mechanisms of integration for STEM disciplines and instructional approaches are largely undertheorized (National Academy of Engineering and National Research Council, 2014). Given the limited research, instructional design for integrated STEM can be informed by the literature on problembased learning $(\mathrm{PBL})$. In a number of reviews on integrated STEM programs, researchers found that integrated STEM programs commonly utilize real-world complex problems as instructional contexts in which students apply knowledge and practices from multiple disciplines (Banks \& Barlex, 2014; Kelley \& Knowles, 2016; Lynn, Moore, Johnson, \& Roehrig, 2016; National Academy of Engineering and National Research Council, 2014). PBL is a well-researched and widely accepted student-centered instructional approach in which students are given an ill-structured real-world problem to investigate viable solutions for by applying knowledge and skills from various sources (Hmelo-Silver, 2004; Savery, 2006). PBL helps students develop knowledge involved in problem solving and cognitive skills such as critical and analytical thinking. Additional characteristics of PBL such as working in collaborative groups and engaging in selfdirected learning lead to learning outcomes such as communication competency and motivation to learn. This approach was succinctly summarized in Hmelo-Silver (2004).

In PBL, student learning centers on a complex problem that does not have a single correct answer. Students work in collaborative groups to identify what they need to learn in order to solve a problem. They engage in self-directed learning (SDL) and then apply their new knowledge to the problem and reflect on what they learned and the effectiveness of the strategies employed.... The goals of PBL include helping students develop 1) flexible knowledge, 2) effective problem-solving skills, 3) SDL skills, 4) effective collaboration skills, and 5) intrinsic motivation. (p.235).

Drawing on this literature, integrated STEM education programs could anticipate similar learning processes and outcomes. PBL is also considered to be critical for integrated STEM education because unstructured problem solving is considered one of the key twenty-first century competencies (Organization for Economic Co-operation and Development, 2016).

PBL in science education typically involves scientific practices, but PBL of integrated STEM education programs have an additional unique feature originating from engineering and technology education. In many integrated STEM education programs design practices in technology and engineering is increasingly emphasized (Fortus, Dershimer, Krajcik, Marx, \& Mamlok-Naaman, 2004; Kelley \& Knowles, 2016; NGSS Lead States, 2013). These are also influenced by art education that addresses design processes reflecting the practices of architects, graphic designers, industrial designers, landscape architects, etc. (Davis, 1998; Sanders, 2012). Many integrated STEM programs include problems that require design in which students create a prototype or a model as a solution for a given problem. In these programs, a set of design practices guide students' problem solving, which is sometimes called design-based activity (e.g., Fortus et al., 2004). Table 1 compares design processes in the area of technology (International Technology Education Association, 2007), engineering (National Research Council, 2010), and art education (Davis, 1998). The design activities in different areas have 
Table 1 Design process in different areas

\begin{tabular}{lll}
\hline Design in technology (International Technology & $\begin{array}{l}\text { Design in engineering (NGSS } \\
\text { Education Association, 2007) }\end{array}$ & Design in art (Davis, 1998) \\
\hline - Identify a design problem & - Define and delimit an & - Identification of a problem \\
- Identify criteria and constraints & engineering problem & - Research and ranking of \\
- Refine a design by using & (design purpose, criteria & priorities \\
prototypes and modeling & and constraints of a & - Viability test of multiple \\
- Evaluate the design solution & successful solution) & solutions through prototypes \\
using conceptual, physical, & - Develop possible solutions: & - Evaluation of objects against \\
and mathematical models & using models including & a socially mediated set of \\
- Develop and produce a product & mathematical models & performance criteria \\
or system & - Optimize the design & \\
- Evaluate final solutions & solution: evaluation of & \\
- Communicate observation, & multiple solutions, making & \\
processes, and results & trade-offs & \\
\hline
\end{tabular}

common processes, from problem identification to the evaluation of multiple solutions because they are all problem-based activities. Furthermore, design problems are all real-world problems that require considerations of constraints, optimization and trade off in design process. Also important is, "concern for users or audiences, human factors," (Davis, 1998, p. 8) which requires empathy, i.e., being sensitive to other people's needs and feelings. In addition, all the design processes are described as teamwork in which collaboration and communication are emphasized (Davis, 1998; National Research Council, 2010).

Design activities provide a context for STEM integration in which learning and application of science and mathematics concepts and practices occur as students work in teams to find solutions for real world problems (Fortus et al., 2004; Kelley \& Knowles, 2016).

Studies about STEM programs have found that explicit scaffolding for integration is essential (Fortus et al., 2004). For example, during simple mechanical device design activities, Crismond (2001) found that inexperienced high school students made few connections between designs and science ideas and rarely applied science ideas learned in one activity to another. On the other hand, experts like university engineering design instructors spontaneously made connections to concepts and utilized concepts in making key design decisions. Similarly, Berland and Steingut (2016) also found that high school students engaged in engineering design tend to focus on completing design tasks without consistent effort to understanding the underlying concepts from mathematics or science. They found that students rarely saw the value of understanding the concepts behind designs. These studies suggest that integrated STEM learning environments should help students investigate relevant concepts and understand how concepts support design goals. In order to avoid students' framing of design activities as mindless trial-and-error exercises (Scherr \& Hammer, 2009), conceptual goals must be made explicit to help students recognize the value of conceptual goals as well as technical goals. In doing so, integrated STEM education can be effectively materialized in the classroom.

Whereas there has been some discussion on similarities and differences between scientific and engineering practices (Fortus et al., 2004; National Academy of Engineering and National Research Council, 2014; NGSS Lead States, 2013) there has been a dearth of research on scientific practices as learning outcomes of integrated STEM programs. In order to make STEM integration meaningful for effective coordination of practices from different disciplines, as well as conceptual learning, further research is needed. 


\section{Contexts of integrated STEAM in South Korea}

A unique feature of integration for STEM in South Korea is an integration of STEM with arts that encompasses fine arts, language arts, liberal arts, and physical arts. STEAM programs in South Korea therefore call for all school subjects to be involved, which can provide rich learning opportunities. Whereas integrated STEAM initiatives in Korea include education both in and out of school (Jho, Hong, \& Song, 2016), most STEAM programs in South Korea focus on programs for school education. Thus, this paper addresses STEAM initiatives for elementary and secondary school programs.

South Korea adopts a national curriculum that covers grades 1 to 12 over 6 years of primary school, and 3 years of lower and 3 years of upper secondary school. The curriculum for grades 1 and 2 is thematically integrated, whereas the curriculum for grades 3 to 12 includes subjects such as science, technology, mathematics, language arts, social studies, and fine arts. Up to lower secondary school, a certain number of class hours across all subjects is required for all students as part of compulsory education. School subjects are more divided in upper secondary school curriculum. For example, science is divided into physics I and physics II, chemistry I and chemistry II, life science I and life science II, earth science I and earth science II. In upper secondary school, students select subjects to specialize in, while a minimum number of credits are required in different subject areas for a diploma.

Although Korean science curriculum addresses STS (science, technology, and society) issues in secondary school sciences, technology is offered as a separate subject required for all upper primary and lower secondary school students. The technology curriculum has evolved a great deal over the past half century. Initially, it addressed building artifacts from wood, metal, electric components and other materials. Since the '90s, engineering and computer use has been included in its content. In a recent revision of the national curriculum, ICT (information and communications technology) content is separated from the technology curriculum, and is required of all secondary school students (Korea Ministry of Education, 2015). Thus, the individual disciplines of STEAM are all required for every secondary school student.

Consistent with the discipline-based curriculum, secondary teachers in South Korea are prepared to teach a specific discipline that they majored in their undergraduate degree program, whereas elementary teachers are prepared to teach all subjects. Science teachers, for example, are prepared in physics, chemistry, biology, or earth science teacher education programs. Similarly, there are separate technology and ICT teacher education programs. There are also secondary teacher education programs at the master's degree level for those who want to teach the discipline they studied for their bachelor's degrees.

The discipline-based school curriculum has changed a little by including programs for "creative experience" (CE) as required credits. These programs are designed by teachers, and provide career exploration and club activities in which interdisciplinary knowledge and skills as well as affective outcomes are expected. Thus, some teachers design CE programs for STEAM education (Korea Foundation for the Advancement and Creativity, 2019). In terms of required course hours, the current 2015 Revised Korean National Curriculum requires 9 13\% of total class hours to be CE across elementary and secondary schools (Korea Ministry of Education, 2015). 


\section{STEAM reform initiative in South Korea}

Since the late '90s, South Korea has observed a decrease in STEM career aspiration among young age groups, and student interest in learning science has remained low (Martin, Mullis, Foy, \& Hooper, 2016). In high schools, students select sciences much less often than the humanities or social studies, and universities are compelled to accept less qualified applicants for STEM majors (Jang \& Kim, 2002). This has led to national concerns for global economic competitiveness.

STEAM reform initiatives have arisen as a result, and their impact has been researched. Significant national funding for research and development for STEAM has been devoted to two major areas: teacher professional development, and STEAM curricular program development. The funding from the Ministry of Education is provided to a government agency called the Korea Foundation for the Advancement and Creativity (KOFAC) that organized programs for STEAM initiatives. Jho et al. (2016) described the entire structure of the initiative in their paper, and in this section, the main programs for STEAM initiatives are briefly reviewed.

\section{Teacher capacity in STEAM}

Since the beginning of the governmental STEAM initiative in 2011, KOFAC has provided teacher professional development for STEAM to both elementary and secondary school teachers through two programs: formal teacher professional development programs (STEAM PD hereafter), and a STEAM research group of teachers (STEAMRGT hereafter) support program. The STEAM PD provides formal courses to teachers of all levels and subjects for free of charge. Whereas the number of course hours has changed since 2011, PD has kept its format of three levels: online courses as an introductory level, a basic blended program, and an advanced blended program. The online course consists of $15 \mathrm{~h}$ and is offered in three types: one for elementary, one for lower secondary and the last for upper secondary school teachers. The courses are offered to teachers across all subjects who are interested in learning about the initiative. The introductory online course provides an overview of STEAM for teachers to understand the policy agenda, its basic goals, and orientation toward approaches to teaching integrated STEAM lessons. Almost half of the course introduces examples of STEAM lessons and demonstrations, which distinguish courses for teachers at different school levels. This introductory online course is available at any time, and teachers get one credit for taking the 15 -h online course. ${ }^{1}$

The basic blended program is designed for any teachers who want to know more about STEAM. This program used to be $60 \mathrm{~h}$-long, but is now $45 \mathrm{~h}$-long, awarding 3 PD credits. The basic program has two major elements: to get teachers familiar with cutting-edge science and technology by observing science and engineering labs and to expose them to STEAM programs developed for schools. The purpose is to get teachers ready for teaching STEAM lessons. In principle, the program addresses competency for teaching STEAM in the classroom including subject matter knowledge, pedagogical content knowledge (PCK) for integrated content, teaching strategies, and teachers' own STEAM literacy development (Korea Foundation for the Advancement and Creativity, 2019). This program includes three, full day, face-to-face workshops in

${ }^{1}$ Currently, teachers in South Korea are recommended to take $60 \mathrm{~h}$ (4 credits) of PD in every five years. 
the summer in which participants visit cutting-edge STEM research labs, take lectures from scientists, engineers, and scholars in the arts and humanities whose work involves interdisciplinary research, get introduced to existing STEAM programs for schools, and develop their own STEAM lesson plans as a team. During the semester following the summer workshop, teachers are required to teach at least 15 STEAM lessons with online consulting for implementation. Toward the end of the semester, teachers are provided with an opportunity to share the results of their STEAM lesson implementation with other participants during a half-day sharing session. Thus, the basic program lasts for about four months in total. Annually, about 300 (150 elementary and 150 secondary) teachers are recruited for the program.

The advanced PD program is open to any STEM teachers or teachers who have finished the basic program. This advanced course used to be $60 \mathrm{~h}$-long, but is now $52 \mathrm{~h}$-long, awarding 3.5 PD credits. The main goal for teachers is to develop competency in creating STEAM contents for teaching (Korea Foundation for the Advancement and Creativity, 2019). Upon completion, teachers are expected to be leaders who can lead STEAM professional development in their schools or local educational agencies. The program consists of a four-day workshop in the summer, followed by mandatory implementation of STEAM lessons in the fall. Annually, about 300 (150 elementary and 150 secondary) teachers are recruited for the course. The formats of the basic and advanced programs are very similar, but the basic program focuses on using ready-made STEAM programs, while the advanced program focuses on the creation of new STEAM lesson materials.

The STEAM-RGT support program exists to support teachers' self-guided professional development by facilitating teacher groups' work as learning communities (Jho et al., 2016). KOFAC calls for STEAM-RGT applications and provides those selected with financial support for attending meetings, and for materials to implement STEAM lessons with. These STEAM-RGTs are responsible for creating STEAM lesson plans, implementing them, and reporting their effects on student learning. In 2011, the first year of the STEAM initiative, 47 STEAM-RGTs from 16 STEAM schools (schools that implement STEAM programs) were funded. In the following year and thereafter, 180 STEAM-RGTs have been selected for funding annually. Half of the groups are composed of elementary teachers, and the other half are composed of secondary teachers. In 2018, the number of STEAM-RGTs funded increased to 230 groups, indicating a rise in governmental support for STEAM PD (Korea Foundation for the Advancement and Creativity, 2019). Although the initial STEAM-RGTs were formed within a school, many STEAM-RGTs are now cross-school communities.

Teachers of STEAM RGTs are provided with an annual opportunity to showcase their teaching in the form of a conference. In addition to financial support, professional development workshops and mentoring have been instituted since 2015 to support STEAM-RGTs. Jho et al. (2016) reports a case study of STEAM-RGTs.

Teachers apply every year for STEAM-RGT support funding, and typically half of the teachers applying are new. It is very common to find teachers who have taken three formal STEAM PDs applying for STEAM-RGT funding, indicating that STEAM PD motivates teachers to further their STEAM competency. 


\section{STEAM curricular program development}

Since 2012, STEAM teaching and learning materials development projects are funded to provide teachers with evidence-based effective STEAM curricular materials. Projects are funded in four areas: thematically integrated STEAM, technology-use STEAM, science and art integrated STEAM, and future career related STEAM. The topics for thematically integrated STEAM programs have been cutting-edge STEM topics such as autonomous vehicles, big data, artificial intelligence, and human brain research. In the area of technology-use STEAM program development, researchers utilized smartphone applications, drones, Arduino and other recent technologies as major technological tools for student learning. Science and art integrated STEAM programs center on music and art curriculum. Future career related STEAM programs introduce recent STEM development such as blockchain technology, data mining, and intelligent farming in relation to a variety of industrial field and jobs.

The number of projects funded has varied annually from 10 to 20 projects per each area. Each project is expected to develop curricular materials for at least 24 class periods in elementary or secondary schools. As a Research and Development project, materials should be tested in schools and their effects should be measured and reported. Also, a common assessment of student interest and teacher satisfaction across all projects is administered to evaluate overall effects. As of June 2019, a total of 666 program modules developed and tested are available at the STEAM homepage hosted by KOFAC (Korea Foundation for the Advancement and Creativity, 2019).

Commissioned by KOFAC, a framework for the STEAM program was developed (Baik et al., 2012) and has been widely used. The framework integrates science learning with design under the motto of 'emotional touch with creative design' (Korea Foundation for the Advancement and Creativity, 2019). The framework utilizes PBL and emphasizes developing talents in integrated STEAM thinking by increasing interest in science and technology, connecting lessons to everyday experience, and developing creative thinking skills. Also emphasized are three features of STEAM lessons including use of personally or socially relevant problems, application of creative design for problem solving and emotional experiences such as interest, a sense of achievement, intellectual satisfaction, passion, confidence, fun, and so on. An example of STEAM curricular materials development project can be found in Kim and Chae (2016). In the study, the research team developed a series of lesson materials (lesson plans, worksheets, and teacher guides) whose goals were to help students understand how a Korean wind instrument works, design their own wind instrument, and perform for an audience. The curricular content included parts of STEAM disciplines across 10 lessons. Students were expected to understand the science of sound through technological measurement, and then engineering the design of an instrument and performing on it were expected to provide emotional experience. This curricular program is typical of science and art integrated STEAM curricular materials development projects that integrate components of the national curriculum of all relevant subjects. Thus, the materials could be easily utilized in schools. Other types of STEAM curricular materials developed were similar in terms of using the PBL centered design framework.

In late 2015 and early 2016, following five years of the initiative, a nationwide survey was administered about the degree to which STEAM programs are provided in schools 
(Korea Foundation for the Advancement and Creativity, 2019). Out of 11,526 elementary and secondary schools in nationwide, $56 \%$ responded to the survey, which showed that $55 \%$ of elementary schools, $48 \%$ of middle schools, and $32 \%$ of high schools offered STEAM lessons to their students. Most of these schools offered STEAM lessons mainly through regular classes (67\% of responses) once or twice a month (60\% of responses). This appeared to be a very fast diffusion over five years. As a reason for offering STEAM lessons, teachers' own initiative was most frequently mentioned (28\% of responses), while support from the school district came second (22\% of responses). This showed that the STEAM initiative has successfully onboarded teachers, and its implementation took both top down and bottom up approaches.

\section{STEAM effects}

Presented in this section are reviews of studies on the effects of the STEAM initiative in three aspects: teacher development in STEAM, meta-analysis of STEAM impact on student learning, and students' perceptions of STEAM lessons.

\section{Teachers in STEAM}

Since the inception of the STEAM reform initiative, teacher capacity building has been emphasized. Research on teachers for STEAM were identified using "teachers" (in Korean) and "STEAM" as search words in two major academic paper search engines in Korea (Korean Studies Information Service System [KISS] and Research Information Sharing Service [RISS]). From the search results, papers whose titles had STEAM and teachers together were included in the review, but non-empirical studies were eliminated. Furthermore, studies about early childhood or preservice teachers were excluded for review because they were not yet the main target of the STEAM initiative. Thus as of 2017, a total of 28 empirical studies about teachers in STEAM reform initiatives

were identified. These studies examined teacher perceptions of STEAM and/or teachers' capacity of implementing STEAM in schools.

\section{Teacher perceptions}

Teacher perceptions of STEAM have been a significant topic of research as teachers are a critical factor in instructional reform (Wallace \& Kang, 2004). In the beginning of the STEAM initiative, a study showed that only $10 \%$ of elementary teachers in a large school district indicated that they were aware of the STEAM initiative (Shin \& Han, 2011). A nationwide survey of secondary teachers also demonstrated that $93 \%$ of teachers either only knew the name, or did not know what the initiative was about at all (Lee et al., 2012). This has changed a great deal over the years to the extent that $28 \%$ of elementary or secondary teachers initiate offering STEAM lessons in schools (Korea Foundation for the Advancement and Creativity, 2019).

Successful implementation of reform initiative requires more than materials, resources, or professional development for teachers. Teachers would respond to STEAM with unique attitudes and beliefs, and thus each teacher would implement STEAM differently. In order to identify necessary supports for various teachers' needs, a diagnostic model called the Concerns-Based Adoption Model (CBAM) has been used as a tool (American Institutes for Research, 2018). In the model, teachers' concerns are 
examined in seven stages of concern including no concern, informational concern, personal concern, managerial concern, consequential concern, collaboration concern, and refocusing concern. Among these stages, consequential concern (concern about the effect on students), collaboration concern (interest in collaborating with colleagues), refocusing concern (interest in adaptation for better effect) are high level concerns that represent proactive attitudes toward implementing the reform initiative. In other words, teachers with high levels of concern for these three types are willing to adopt and/or adapt the reform initiative.

Six studies used parts of, or a complete CBAM survey, to identify teachers' perceptions of STEAM. Two of the studies examined elementary teachers' concerns for STEAM in which one of them surveyed teachers in STEAM schools and the others surveyed teachers in normal schools (Chae \& Noh, 2014; Lee, 2014a). Studies showed that more teachers in STEAM schools demonstrated higher level concerns. For example, the degree of refocusing concern in STEAM schools was on an average 84 on the scale, whereas the average degree in normal schools was 58. Similar trends were also found in other studies that examined both elementary and secondary school teachers. Teachers in STEAM schools or teachers of STEAM-RGT had more high-level concerns. Taken together, the more teachers were involved in STEAM, the higher level of concerns are prevalent among teachers.

A study compared perceptions of teachers who had been leaders of the STEAM initiative in their schools and those who never experienced STEAM (Moon, 2015). In the study, teachers who were leaders of STEAM demonstrated high scores on consequential, collaboration and refocusing concerns. The other group scored highly on managerial concern. Interviews with these teachers confirmed the survey results, and also revealed different perceptions about STEAM between the two groups of teachers. Through experiences, STEAM leaders tended to view STEAM lessons as flexible, so that they could be adapted to local needs. They were more confident in its effect on student learning than those who didn't teach STEAM. The other group, however, tended to view STEAM as a highly structured teaching model and as a reform fad that would soon to be replaced with another fad. The difference between the two groups, teachers who taught STEAM, and those who did not teach STEAM, was also found in a study about collective teacher efficacy (Lee, 2014b). Whereas teachers' collective teacher efficacy (efficacy belief about teachers in one's own school) was not related to teachers' years of teaching, teachers who taught STEAM lessons demonstrated significantly higher collective teacher efficacy than those who did not. Again, the more teachers were involved in STEAM the more proactive and confident they were in STEAM.

A KOFAC commissioned survey report on teachers' perceptions of the STEAM lessons provided an overall view of teachers' own STEAM teaching (Kang et al., 2018). Using the same survey questions responses from 1,815 elementary and secondary teachers were collected between 2014 and 2017. Eight survey items in the 5-scale Likert asked about the innovativeness of STEAM lessons, their relation to cutting-edge STEM, connection to everyday life, and ability to stimulate student interest in learning STEM. The average response was positive, ranging from 4.1 to 4.3 each year. Overall, teachers who implemented STEAM seemed to perceive that their teaching met the STEAM reform intention. 
Taken together, these studies showed that in a relatively short period of time, the STEAM initiative became widely known among teachers, and that a rather large proportion of teachers implemented STEAM in schools. Studies also found that the teachers who taught STEAM had positive perceptions of STEAM, meeting the goals of the STEAM initiative.

\section{Teacher implementation capacity}

When it comes to implementation, teaching capacity, and other challenges teachers perceive matter the most. Studies about teacher professional development have supposedly addressed how much capacity teachers were able to build through STEAM PD. For example, Han, Hwang, and Yoo (2016) examined who was participating in STEAM PD and the effect of STEAM PD since the inception of STEAM reform. Over three years, 696 teachers participated in PD at the advanced level. Thirty-eight percent were elementary teachers, and $65 \%$ had more than 10 years of experience in teaching. Also, $78 \%$ of the secondary teachers were teaching science. Thus, it seems that more experienced teachers and science teachers tended to pay attention to the initiative. Using surveys and reflection papers of 696 participants, the study found that professional development programs were effective in improving teachers' STEAM teaching competency thanks to built-in implementation and reflection elements. Participant teachers reported that a cycle of STEAM lesson planning during face-to-face meetings over the summer, implementation of the lessons in the subsequent semester, and sharing of implementation results were useful for them in building confidence and improving their STEAM teaching capacity (Han et al., 2016).

Park, Byun, and Sim (2016) examined how teachers in STEAM schools implement STEAM lessons in regards to frequency and curriculum organizations. Responses from a total of 705 teachers from 252 elementary and secondary STEAM schools were analyzed. The results showed that about $70 \%$ of teachers taught STEAM lessons either an hour every week or every other week. Given the study was conducted at the end of the fifth year of the initiative, the results showed a very successful rate of teacher adoption of STEAM in schools.

The study also showed that elementary and lower secondary teachers (66\% of elementary and 74\% of lower secondary school teachers) provided STEAM mostly as a part of regular curriculum, but only $50 \%$ of upper secondary school teachers taught STEAM in regular classes. Because the Korean curriculum is discipline-based, it is important to know whether STEAM lessons are taught during classes of various subjects to meet the goal of interdisciplinary or convergence education. The results showed that $75 \%$ of elementary teachers taught STEAM in science class, while $25 \%$ of lower secondary school teachers and 50\% of upper secondary school teachers taught STEAM in science class. These results should be carefully interpreted. In general, STEAM lessons were associated with science more than any other subjects. Given the general trend, it is plausible that elementary teachers who teach all subjects tended to consider science as the main content of STEAM lessons, while lower secondary school teachers treated it as being multidisciplinary, encouraging teachers across multiple subjects to teach STEAM lessons. With regard to upper secondary schools, only half of the teachers taught STEAM lessons in regular classes, while science was the dominant subject to be used. 
On the other hand, special classes for STEAM could be interdisciplinary in its nature. Further research on patterns of teacher implementation is necessary.

To find out necessary support for teachers' implementation of STEAM, Park et al. (2016) also surveyed what teachers felt challenging in teaching STEAM lessons, and whether the perceived challenges differ according to teachers' years of teaching. They found that there was no significant difference in teachers' perceived challenges. All the teachers in the study felt they needed more time to prepare STEAM lessons, though worried about increasing their workloads due to STEAM.

More detailed challenges were revealed in another study. J.-M. Lee and Shin (2014) interviewed 25 elementary teachers about their perceived challenges in teaching STEAM lessons. The common difficulties cited included curriculum reorganization and constructing STEAM lesson materials, guiding students' group activities, conducting proper student assessment, and a conservative school climate. Addressing these challenges experienced by teachers would be critical for successful STEAM in schools.

\section{Connections between perceptions and implementations}

There has been little research connecting teacher perceptions and implementations. To gain insight into potential connections, the results of three research studies that reported interviews about teachers' perceptions and implementations (Kang et al., 2017; Kang \& Kim, 2015; Kang, Lee, Rho, \& Yoo, 2018) were reanalyzed for this review. Among the total of 25 teachers interviewed in those reports, 2 secondary teachers had no experience teaching STEAM lessons, 4 of the teachers taught STEAM but stopped teaching STEAM lessons (drop-outs), and the other 19 teachers were teaching STEAM at the time of the interview. Among the 25 teachers, 10 were teaching in elementary schools, 9 were teaching science, 2 were teaching mathematics, 1 was teaching technology, and 3 were teaching social studies, English and art respectively.

All the teachers interviewed perceived STEAM as a way to integrate two or more disciplines in using everyday connections. Also, they believed that STEAM lessons could be a way to stimulate student interest in science learning and school learning in general. However, when the teachers had to elaborate on how to teach STEAM, their ideas diverged. To the two secondary teachers who never taught STEAM, STEAM was a way to extend students' science learning to be more well-rounded in terms of content, while student problem solving or design element of STEAM was not essential. Thus, integration became, "addition of extra content to the existing science content to be covered" (Kang \& Kim, 2015). A similar view was also demonstrated by most of the elementary teachers. Although they were teaching all subjects and thus could have easily integrated subjects into STEAM lessons, most of the elementary teachers viewed STEAM lessons as science with some 'spice' of relevant content from different subjects. An issue salient to the elementary teachers was to, "make sure the content to be integrated is in the curriculum for the grade" (Kang et al., 2017). The teachers were concerned about teaching at their students' levels and constrained the content of STEAM lessons to the curriculum for the grade of their teaching. This result corroborated survey results by Park et al. (2016) in which most elementary teachers stated they taught STEAM in science classes. To these teachers, the main purpose of integrated STEAM was to make science intriguing and engaging. 
On the other hand, most secondary teachers expressed that they felt a need to schedule a special class for STEAM for a number of reasons. They viewed STEAM as requiring, "a special way of teaching" that incorporated problem- or project-based approaches with multidisciplinary content. Thus, these teachers preferred club activities or special classes provided afterschool where students could be engaged in STEAM activities for an extended time. This made the subject-specific school schedule irrelevant. Again, this result corroborated survey results by Park et al. (2016) that showed half of upper secondary school teachers taught STEAM in special classes. To these teachers, the discipline-based curriculum was a serious barrier to integrated STEAM, and they avoided the barrier by using non-regular class time.

However, some of these teachers had also taught STEAM in regular class periods, in collaboration with teachers across multiple disciplines. For example, an art teacher, technology teacher and a science teacher planned a lesson on 'light' as a theme, where the culminating project was to build an LED lamp in a variety of shapes and colors of their choice. For this project, students learned basics in each subject, while the project was completed in technology class (Kang et al., 2017).

The findings showed that seemingly the same ideas about the nature of integrated STEAM actually diverged in practice. Thus, understanding of teachers' perceptions of STEAM should be accompanied by understanding of their pedagogical practices (Kang \& Wallace, 2005).

\section{STEAM teacher drop-outs}

The four teachers who stopped teaching STEAM had a number of reasons. Two of them (teacher A and B hereafter) had transferred to different schools. Teacher A's new school was running a different reform initiative for which he had to work on. He wanted to continue teaching STEAM, but he felt it was not possible without school support. On the other hand, teacher B was optimistic about continuing to teach STEAM lessons, but she was, "looking for teachers who could work together" (Kang et al., 2017). The other two drop-outs were both math teachers. They felt STEAM did not properly address math content and wanted to have more mathematics-focused STEAM programs. These issues of attrition can be generalized to any teachers who want to teach STEAM lessons. Changing schools always requires finding teachers at the new school to collaborate with on creating and implementing STEAM lessons. This might be more challenging when a new school aims at a different educational agenda. Also, teachers who are concerned with content coverage may feel that interdisciplinary lessons fall short of enough in-depth content learning.

STEAM-RGT could be a solution for the issue of school transfers and developing new STEAM programs to meet the teachers' needs. When there is a lack of within school support, teachers can get support from STEAM-RGTs when they are formed with member of different schools. Also, STEAM-RGTs can be formed by teachers who share concerns and goals such as mathematics-focused STEAM program development.

Little research has been conducted about how STEAM-RGT works. Whereas teachers' learning community has been researched widely (Cochran-Smith \& Lytle, 1999; McLaughlin \& Talbert, 2001; Wineburg \& Grossman, 2000), STEAM-RGT is unique as they focus on developing interdisciplinary curricular materials. Two studies 
in South Korea were found to have examined STEAM-TRG groups' work. In particular, one study examined how teachers of different disciplines or subject matter had overcome disciplinary differences and were able to work together to create STEAM lessons collaboratively (Lee, Lee, \& Ha, 2013). To understand the communication processes, the researchers interviewed teachers, observed teachers' group discussions, and examined reflective essays. The study used the notion of a trading zone by Galison (2010) in its analysis, showing an evolutionary process from the beginning of group formation until the implementation of collaboratively developed STEAM lessons. In the process, teachers encountered and overcame a number of challenges including cultural and linguistic differences across disciplines, different motivations for integration, and various understandings of what makes meaningful integration. This study and the other (Jho et al., 2016) examined successful or exemplary cases of on-going STEAM-RGTs. To find out ways to facilitate and support STEAM-RGTs, further research on the process of continuation or discontinuation of STEAM-RGTs and related processes is needed.

\section{Meta-analysis of STEAM impact on student learning}

Many studies in South Korea examined STEAM effects on student learning. Two major academic search engines in Korea (RISS \& KISS) were used to identify research papers on STEAM's impact on student learning, using "learning" (in Korean) and "STEAM" as search words. Eliminating all studies about pre-school students, 357 papers published between 2011 and 2016 were found. Of these, 160 addressed student learning from STEAM lessons empirically. These studies report different sizes of STEAM effect on students learning while their measure of student learning and aspects of student learning were all different in one way or another. In this context, a meta-analysis can be a good way to estimate the overall effect of STEAM on student learning. Most studies about student learning from STEAM showed positive effects, but the size of the effects differed across studies. Furthermore, some studies found statistical significance in certain variables while others did not. Meta-analysis is a statistical procedure that can help make sense of these differences. When the treatment effect (or effect size) is inconsistent from one study to the next, meta-analysis can be used to identify a common effect by treating each study as one data point in a larger population of studies (Borenstein, Hedges, Higgins, \& Rothstein, 2009; Hunter, 2004).

A total of 11 meta-analyses were published in peer-reviewed journals in Korea from 2012 till 2018. Among these 11 studies, 6 analyzed papers only on STEAM in elementary and secondary schools that STEAM initiative aims. Table 2 provided an overview of the 6 studies.

The number of papers analyzed in the studies varied not only because of the time of study, but also because some of the studies included non-experimental study (experimental group only design) while the others included only quasi-experimental studies.

The meta-analysis results showed medium to high effects on student learning (Table 2). These studies also examined a number of variables that could moderate the effect. The moderators examined included sample size, number of STEAM class periods, lesson product types, lesson mediums, student types (gifted or not), grades or school levels, types of emotional experience, number of integrated subjects, class types (regular or non-regular class), and gender. Most of these variables 
Table 2 An overview of meta-analysis studies

\begin{tabular}{|c|c|c|c|c|}
\hline Paper information & $\begin{array}{l}\text { No. of papers } \\
\text { analyzed }\end{array}$ & $\begin{array}{l}{ }^{a} \text { No. of } \\
\text { effect size }\end{array}$ & $\begin{array}{l}\text { Mean effect size (Target } \\
\text { dependent variable) }\end{array}$ & Note \\
\hline Kim and Won (2014) & 15 & 68 & 0.703 (creativity) & Elementary student only \\
\hline Rho and Yoo (2016) & 34 & 33 & 0.557 (affective domain) & \\
\hline Kim and Kim (2016) & 30 & 73 & 0.628 & Technology-centered STEAM \\
\hline Cho (2018) & 22 & 48 & $\begin{array}{l}0.788 \text { (cognitive domain) } \\
0.898 \text { (affective domain) }\end{array}$ & Technology-centered STEAM \\
\hline Kang, Lee, et al. (2018) & 60 & 172 & $\begin{array}{l}0.520 \text { (all dependent } \\
\text { variables reported) }\end{array}$ & \\
\hline Shin (2018) & 95 & 316 & $\begin{array}{l}0.652 \text { (all dependent } \\
\text { variables reported) }\end{array}$ & Elementary students only \\
\hline
\end{tabular}

${ }^{a}$ Because one study may measure multiple variables and provide multiple effect sizes, typically the number of effect sizes is bigger than the number of papers

did not significantly moderate the effect size. The moderators that had significant effects in some studies were non-regular class type (effect on affective domain, Cho, 2018; Kim \& Kim, 2016), use of ICT mobile tools (effect on affective domain, Rho \& Yoo, 2016), and elementary level (effect on technology-centered STEAM, Kim \& Kim, 2016). However, the same moderators did not have significant effects in other studies (Kang, Lee, et al., 2018; Shin, 2018).

Given the overall positive effects of STEAM on student learning across all metaanalyses, the effect sizes varied across diverse dependent variables. Among the six studies, two that examined all the dependent variables in research provided an overall picture of STEAM effects on students. The mean effect size in the two studies was medium (Table 2). Kang, Lee, et al. (2018) analyzed research published between 2011 and 2016 while Shin (2018) analyzed research published between 2012 and 2018. Also, the two analyses were different in that Kang, Lee, et al. (2018) examined STEAM effect on both elementary and secondary, but Shin (2018) only analyzed STEAM effect only on elementary students. Although their analysis methods were different and thus the results were not directly comparable, the end results from the two studies showed to be quite similar (Table 3).

The two studies found significant effects in similar variables. STEAM seemed to have different degrees of effects on various aspects of learning outcomes. More effective aspects included affective domain, career aspiration, thinking skills and so on. These results were in alignment with the goals of STEAM initiative that wants to go beyond content learning.

Table 3 Dependent variables in two studies

\begin{tabular}{ll}
\hline Kang, Lee, et al. (2018) & Shin (2018) \\
\hline 1. Academic achievement & 1. Academic achievement \\
**2. Affective achievement & a2. Affective achievement \\
*3. Thinking skills & b3. Creativity in cognition \\
*4. Character: emotional experience, caring & b4. Creativity in character (persistence, curiosity, etc.) \\
**5. STEM career: aspiration, attitudes & 5. Career aspiration \& aptitude \\
6. ICT or environmental literacy & 6. ICT skills, inquiry skills, mathematical skills \\
7. Creativity: creative problem-solving skills & a7. Creativity: creative problem-solving skills
\end{tabular}

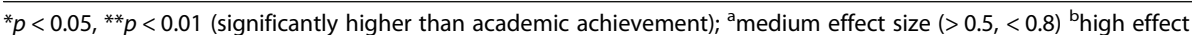
size $(>0.8)$ 


\section{Student perceptions of STEAM}

As reviewed in the previous section students' affective domains such as attitudes towards STEM and interest in learning STEM were influenced the most by STEAM programs. However, there is little research on how students perceive STEAM lessons in comparison with regular ones. Annual survey reports on student perceptions of STEAM programs commissioned by KOFAC and two research papers provided an overall picture of how students experienced STEAM in schools (Kang et al., 2017, Kang, Lee, et al., 2018; Lee, Chung Lee, Shin, Chung, \& Oh, 2013; Lim et al., 2014. A report examining the long-term effects of STEAM as perceived by students also exists (Kang, Im, et al., 2018).

\section{Distinct features of STEAM classes}

The annual commissioned reports used the same survey questions to find out student perception of and satisfaction with STEAM lessons implemented in STEAM schools and lessons provided by STEM-RGTs or STEAM curricular program developers funded by KOFAC. Students' perceptions about STEAM lessons were examined with eight questions concerning general satisfaction, a sense of fun, a sense of challenge, and the features of STEAM lessons they liked the most or least. Among the questions, responses to two questions revealed how students experienced STEAM class. Students were asked about the most distinct feature of STEAM class in comparison with regular classes, and which aspect of STEAM classes they favored the most. Students had to choose one feature from six: integration of subjects, student-centered focus, group work, self-guided work, everyday relevance of STEM, and STEM career information. Over the past three years, every year exhibited similar results. More than half of all students, both elementary and secondary, selected either the integration of subjects or group work as the most distinctive feature of STEAM classes, also nominating either of the two as their favorite feature of STEAM classes.

Students' perceptions were presented in their own words by Lim et al. (2014). The study analyzed interviews with 24 6th grade students about their perceptions of STEAM after 12 class periods of a STEAM unit on energy. The students indicated that they enjoyed student-centered design activities and discussion on diverse topics about a problem (interdisciplinary nature). They stated that they were, "more focused than listening to the teacher talking," and that they found discussion on diverse topics engaging (p. 125). On the other hand, the students stated that thinking for themselves and coordinating different ideas within a group were very challenging. These results aligned with the annual student survey results. Further qualitative in-depth research on student experience with STEAM would help to understand how STEAM can be effective and may shed light on ways to make STEAM learning more meaningful.

J. Lee, T. Lee, Shin, Chung, \& Oh, (2013) examined students' pictures of people talented in convergence, and whether the images differed between students who had taken STEAM classes versus those who hadn't. In the study, students were asked to draw a picture of a person talented in convergence with a brief explanation. Analysis of the drawings showed a difference between two groups of lower secondary school students $(n=90)$. Students who had previously taken STEAM classes $(n=41)$ presented images with collective cognitive processing $(39 \%)$ such 
as images of many people sharing ideas or different experts working together, but none of students from the no STEAM experience group $(n=49)$ presented collective cognitive processing. Most of those from the non-experienced group depicted images of individual cognitive processing such as famous individuals, a person thinking alone $(76 \%)$ or famous inventions. Although further research on where their images came from is necessary, the results along with the survey results in other studies indicate that STEAM class could provide proper images of the interdisciplinary nature of current STEM fields. Also, students would understand what to expect when they choose a career in any STEM field.

\section{Student perceptions on long-term effect}

The quantitative studies about the effect of STEAM on student learning, as shown in the meta-analysis papers, demonstrated positive immediate effects because they measured student learning outcomes soon after STEAM interventions. However, there was a lack of research on long-term effects. A KOFAC commissioned report surveyed college students who had experienced STEAM programs in secondary school years, and asked those who with no STEAM experience to compare their perceived effects on STEAM or science-related school work during secondary school years (Kang, Im, et al., 2018). A sample of those who had STEAM experience were also interviewed about their views on the effects of STEAM lessons and its perceived long-term effects.

With comparable proportions of undergraduate majors, 157 STEAM experienced and 142 non-experienced college students' survey responses were analyzed. A total of 37 from the STEAM experienced group were interviewed. All the interviewees were college freshmen or sophomores who were mostly science or engineering majors, apart from a few nursing majors.

The main comparison made between the two groups from the survey was whether they felt STEAM experience (for experienced group) or science related school work (for non-experienced group) improved 13 specific core competencies promoted by STEAM and the national science education curriculum. The college students were asked how effective STEAM (or science-related schools work) was on a 5-scale for each competency. With independent t-tests, it was found that on all items except 'confidence in science and mathematics', the STEAM experienced group rated significantly higher $(p<.001)$ than those without experience (Table 4).

Interview data complemented the survey results. The most frequently mentioned positive aspect of STEAM lessons from interviews was self-directed problem solving. Out of this type of activities, they stated, they gained confidence, identity as science learners, and a sense of achievement. Interviews also showed that challenges given during the self-directed problem solving were closely related to the increase in self-esteem. This was also related to entrepreneurship. Many of the interviewees stated that they tended to try out things that were seemingly difficult thanks to their STEAM experience. This corroborated meta-analysis results in that the students perceived affective or emotional experience as significant outcomes.

Another common positive aspect of STEAM was teamwork. The students related their improved ability of communication and caring for team members to long-term group work they had in STEAM classes. These students felt that their STEAM 
Table 4 Student perceived STEAM effect on core competencies (modified from Kang, Im, et al., 2018, p. 160)

\begin{tabular}{lll}
\hline Core competency & $\begin{array}{l}\text { STEAM experienced } \\
\text { group mean (SD) }(n=157)\end{array}$ & $\begin{array}{l}\text { Non-experienced group } \\
\text { mean (SD) }(n=142)\end{array}$ \\
\hline 1. interest in science & $4.32(.691)$ & $3.62(1.023)$ \\
2. multidisciplinary thinking & $4.20(.755)$ & $2.92(1.042)$ \\
3. communication & $4.24(.752)$ & $2.84(1.102)$ \\
4. creativity & $4.32(.835)$ & $2.77(1.094)$ \\
5. problem-solving & $4.24(.780)$ & $3.58(.992)$ \\
6. real life application & $3.73(.945)$ & $2.88(1.114)$ \\
7. self-directed learning & $3.95(.883)$ & $3.43(1.145)$ \\
8. inquiry design skills & $4.32(.736)$ & $3.00(1.092)$ \\
9. persistence, concentration & $4.32(.794)$ & $3.58(1.151)$ \\
10. technology or tool use & $4.39(.740)$ & $3.19(1.142)$ \\
11. confidence in science and mathematics & $3.71(.961)$ & $3.68(.992)$ \\
12. caring team members & $4.37(.728)$ & $3.17(1.104)$ \\
13. production of inquiry or projects & $4.36(.832)$ & $2.79(1.208)$ \\
\hline
\end{tabular}

experiences were unique and different from typical school learning. This was particularly salient in their teamwork skills because they could easily compare themselves with others during college team projects.

In the interviews, the positive effects from STEAM experiences were commonly related to their perceived long-term effects on their college studies. Most of the students stated that self-directed learning skills and teamwork skills helped their college classes and many of them contrasted themselves with those who were weak in the skills who had no previous STEAM experience.

The interviews also showed that the STEAM effects on affective domains were related to their decisions regarding college majors and career aspirations. In particular, many engineering and science majors in the interview stated that their decisions about their college majors were informed by their STEAM experience.

Interestingly, many of the engineering majors mentioned that their STEAM experience directly helped their coursework, because they had very similar experiences in high school STEAM lessons. Apparently, engineering design elements of STEAM prepared engineering majors for their college work.

Taken together, the results from interviews with college students who had experienced STEAM corroborated meta-analysis results. Also, the results provided a glimpse of how STEAM programs could have produced relatively long-term effects on students.

\section{Conclusions and implications}

This study examined the STEAM initiative in South Korea and reviewed the studies about its effects on teaching and learning. Based on a literature review, evidence of the effects, challenges, and further research topics were identified. Studies have shown that the STEAM initiative was well received by teachers. In terms of increasing teacher capacity to teach integrated STEAM lessons, studies in South Korea found that teacher professional development courses increased teachers' recognition of the initiative and confidence in teaching STEAM. Teacher interviews showed that coaching in classroom practices within teachers' professional development was helpful. This could be related 
to studies about teacher perceptions that revealed differences between teachers who had taught STEAM lessons (teachers in STEAM schools or STEAM-RGTs), and those who had not. Teachers' STEAM teaching capacity could be strengthened by professional development with elements of collaborative and/or reflective classroom implementation. Further research on effective STEAM professional development program design principles is necessary.

It was also found that there was a lack of research on the connections between teachers' perceptions of STEAM and their classroom practices. In particular, the high frequency of using science classes for teaching STEAM should be carefully examined in relation to how teachers perceive what STEAM is. Unless science classes are allocated more time in the curriculum, STEAM would be a burden to science teaching, when STEAM is considered less multidisciplinary learning, and more of a new way of teaching science. Furthermore, the interdisciplinary nature of STEAM would be lost, failing to achieve the goal of 'creative convergence' in learning. Given the current discipline-based curriculum, STEAM should be carefully conceptualized, and strategies for teacher collaborations across different subjects should be carefully planned.

As for STEAM effects on student learning, a number of meta-analyses provided an overall picture of the effect. The studies reported that the STEAM initiative, to some degree, achieved intended learning outcomes. Meta-analysis showed that students' experiences with STEAM were effective in cognitive and affective learning. In particular, the effect was higher in affective domains. Interviews with college students who had STEAM experiences in grade schools showed that the effects could be long-term. These students perceived that their earlier STEAM experience better prepared them for college, and improved competencies such as communication and teamwork skills. On the other hand, the meta-analysis studies showed that there were few significant mediating factors. For example, it was found that student grades, lesson medium, and so on did not have significant effects. Further in-depth research on how STEAM programs interact with students is necessary to understand how those variables function in the classroom.

This review demonstrated that the integrated STEAM initiative in South Korea somewhat achieved its goals, while revealing shortcomings in both research and practice. As STEAM has utilized PBL, the positive outcomes were consistent with those expected from PBL (Hmelo-Silver, 2004). However, there is a lack of research on the effect of the interdisciplinary nature of STEAM. The interdisciplinary aspect of STEAM should be further studied as a unique feature and goal in order to inform ways of designing meaningful interdisciplinary activities for STEAM. Given the various methods by which to make learning activities interdisciplinary (Banks \& Barlex, 2014; National Research Council, 2012), further research on different effects from different ways of integration is necessary. Research on these topics should be accompanied by research on student learning process and its effects. Linking program designs and implementations with specific outcomes should further develop integrated STEAM programs and their effects.

Given the global emphasis on twenty-first century competencies (e.g., Organization for Economic Co-operation and Development, 2016; Partnership for 21st Century Learning, 2009), the integrated STEAM initiative in South Korea and similar initiatives in other countries would have continuing, if not increasing, momentum. Thus, this study provides a glimpse of what can be achieved through such efforts, and what should be further researched for better theory and practice. 


\section{Abbreviations}

ICT: Information and communications technology; ITEA: International Technology Education Association; KOFAC: Korea Foundation for the Advancement and Creativity; KISS: Korean Studies Information Service System; NAE: US National Academy of Engineering; NGSS: US Next Generation Science Standards includes engineering design and practices as primary elements of science education; NRC: US National Research Council; OECD: Organization for Economic Cooperation and Development; PBL: Problem-based learning; PCK: Pedagogical content knowledge; RISS: Research Information Sharing Service; STEAM: Integrated science, technology, engineering, arts, and mathematics education; STEAM-RGT: STEAM research group of teachers; STEM: Science, technology, engineering, and mathematics; STS: Science, technology, and society

\section{Acknowledgements}

Not applicable.

\section{About the author}

Nam-Hwa Kang (Email: nama.kang@knue.ac.kr) is a professor at Korea National University of Education (KNUE), South Korea. Before she joined KNUE in 2012, she was an assistant professor at University of Nevada, Las Vegas, US, and an assistant and associate professor at Oregon State University, US. Her research centers on science teaching practices in relation to epistemic practices in science. She published papers that address connections between science teacher beliefs about science learning, science inquiry, modelling in science, and scientific argumentation and teaching practices. Her recent projects include defining and supporting science teaching competency development and assessing the impact of integrated STEAM (Science-Technology-Engineering-Arts-Mathematics) reform. She directed research and evaluation of national STEAM initiative for three years. Currently, she is the editor-in-chief of a journal, Innovation \& Education published by BMC (part of Springer Nature) and an associate editor of Asia-Pacific Science Education published by Springer Open.

\section{Authors' contributions}

NK reviewed and wrote the paper. The author declares that she has no competing interests.

\section{Funding}

Not applicable.

\section{Availability of data and materials}

Not applicable.

\section{Competing interests}

The author declares that she has no competing interests.

Received: 10 May 2019 Accepted: 1 July 2019

\section{References}

American Institutes for Research (2018). Concerns-Based Adoption Model (CBAM). Retrieved from http://www.sedl.org/cbam/ Accessed 2 May 2018.

Baik, Y., Kim, Y., Nho, S., Lee, J., Jung, J., Han, H., et al. (2012). 융합인재교육(STEAM) 실행 방향 정립을 위한 기초연구 [A study on the action plans for STEAM education]. Seoul: KOFAC.

Banks, F., \& Barlex, D. (2014). Teaching STEM in the secondary school. New York: Routledge.

Berland, L. K., \& Steingut, R. (2016). Explaining variation in student efforts towards using math and science knowledge in engineering contexts. International Journal of Science Education, 38(18), 2742-2761. https://doi.org/10.1080/09500693.2016.1260179.

Borenstein, M., Hedges, L. V., Higgins, J. P. T., \& Rothstein, H. R. (2009). Introduction to meta-analysis. Chichester: Wiley.

Bybee, R. W. (2010). What is STEM education? Science, 329(5995), 996. https://doi.org/10.1126/science.1194998.

Chae, H., \& Noh, S.-G. (2014). 2009 개정 초등학교 과학과 교육과정의 융합인재교육(STEAM)에 대한 교사의 관심도와 실 행 수준 분석 [Analysis of teachers' stages of concern and levels of use on STEAM of the 2009 elementary science curriculum]. Journal of Korean Elementary Science Education, 33(4), 634-645.

Cho, Y.-J. (2018). 실과, 기술 · 가정의 STEAM 교육 프로그램 효과에 관한 메타분석 [A meta-analysis on the effectiveness of STEAM program in practical arts education and technology.home economics]. The Journal of Practical Arts Education Research, 24(1), 155-174.

Cochran-Smith, M., \& Lytle, S. (1999). Teacher learning communities. Review of Research in Education, 24, $24-32$.

Crismond, D. (2001). Learning and using science ideas when doing investigate-and-redesign tasks: A study of naive, novice, and expert designers doing constrained and scaffolded design work. Journal of Research in Science Teaching, 38(7), 791-820. https://doi.org/10.1002/tea.1032

Davis, M. (1998). Making a case for design-based learning. Arts Education Policy Review, 100(2), 7-15. https://doi.org/10.1080/1 0632919809599450

Fortus, D., Dershimer, R. C., Krajcik, J., Marx, R. W., \& Mamlok-Naaman, R. (2004). Design-based science and student learning. Journal of Research in Science Teaching, 41(10), 1081-1110. https://doi.org/10.1002/tea.20040.

Galison, P. (2010). Trading with the enemy. In Trading zones and interactional expertise (pp. 25-52). Cambridge: The MIT Press.

Han, I., Hwang, S., \& Yoo, J. (2016). STEAM 심화과정 교사연수 프로그램 개발 및 운영 [Development and management of the advanced STEAM teacher training program]. Journal of the Korean Association for Research in Science Education, 36(3), 399-411.

Henriksen, D. (2014). Full STEAM ahead: Creativity in excellent STEM teaching practices. STEAM, 1(2), 1-9. https://doi.org/1 0.5642 steam.20140102.15.

Hmelo-Silver, C. E. (2004). Problem-based learning: What and how do students learn? Educational Psychology Review, 16(3), 235-266. https://doi.org/10.1023/B:EDPR.0000034022.16470.f3 
Hunter, J. E. (2004). Methods of meta-analysis: Correcting error and bias in research findings (2nd ed.). Thousand Oaks: Sage. International Technology Education Association. (2007). Standards for technological literacy: Content for the study of technology (3rd ed.). Reston: International Technology Education Association Available from https:/www.iteea.org/default.aspx?id= $37346 \& q=$ standards.

Jang, C. W., \& Kim, S. Y. (2002). 구조적 측면에서 접근한 이공계 기피 현상의 원인분석과 정책과제 [factor analyses for the avoidance of science \& technical engineering colleges and policy implications in Korea]. The Journal of Vocational Education Research, 21(2), 115-140.

Jho, H., Hong, O., \& Song, J. (2016). An analysis of STEM/STEAM teacher education in Korea with a case study of two schools from a community of practice perspective. Eurasia Journal of Mathematics, Science and Technology Education, 12(7), 1843-1862. https://doi.org/10.12973/eurasia.2016.1538a.

Kang, N.-H., Byun, S., Im, S., Yoo, J. E., Lee, N., Rho, M., \& Jung, J. Y. (2017). 2016 융합인재교육(STEEAM) 효과성 분석 [the effects of STEAM projects: Year 2016 analysis]. Seoul: KOFAC.

Kang, N.-H., Im, S., Byun, S., Lee, E., Lee, N., Oh, K., \& Seo, Y. (2018). 2017 융합인재교육(STEEAM) 효과성 분석 [the effects of STEAM projects: Year 2017] analysis. Seoul: KOFAC.

Kang, N.-H., \& Kim, S. (2015). 교사의 관점으로 본 STEAM 교육 [teachers' perceptions of STEAM education]. Curriculum and Instruction Journal, 15(2), 2-9.

Kang, N., Lee, N., Rho, M., \& Yoo, J. E. (2018). 융합인재교육(STEAM) 프로그램이 학생에 미친 효과에 대한 메타분석 [Meta-analysis of STEAM (science, technology, engineering, arts, mathematics) program effect on student learning]. Journal of the Korean Association for Science Education, 38(6), 875-883. https://doi.org/10.14697/jkase.2018.38.6.875.

Kelley, T. R., \& Knowles, J. G. (2016). A conceptual framework for integrated STEM education. International Journal of STEM Education, 3(1), 11. https://doi.org/10.1186/s40594-016-0046-z.

Kang, N.H., \& Wallace, C. S. (2005). Secondary science teachers' use of laboratory activities: Linking epistemological beliefs, goals, and practices. Science Education, 89(1), 140-165. https://doi.org/10.1002/sce.20013.

Kim, H., \& Chae, D. H. (2016). The development and application of a STEAM program based on traditional Korean culture. Eurasia Journal of Mathematics, Science and Technology Education, 12(7), 1925-1936. https://doi.org/10.12973/eurasia.2016.1539a.

Kim, M., \& Kim, T. (2016). 기술 중심 융합교육(SETAM) 효과에 대한 메타분석 [meta-analysis on the effect of convergence education (STEAM) based on technology]. The Journal of Korean Practical Arts Education, 22(4), 65-83.

Kim, J. W., \& Won, H. H. (2014). 초등학교 STEAM 교육의 창의성 효과에 대한 메타분석 [the effect of creativity in STEAM education]. Journal of Educational Evaluation, 27(4), 965-985.

Korea Foundation for the Advancement and Creativity (2019). About STEAM. Retrieved from https://steam.kofac.re.kr/?page_id=11269

Korea Ministry of Education. (2015). 2015 개정 과학과 교육과정 [The 2015 Revised Science Curriculum]. Report no. 2015-74. Sejong: Author.

Lee, M.S. (2014a). 융합교육 연수 경험과 수업 적용 여부가 STEAM 관심단계에 미치는 영향 [the effect of teacher's training and teaching experience for integrative education on teacher's concerns]. Korean Journal of Educational Research 52(1), 251-271.

Lee, M.S. (2014b). 융합교육과정에 대한 교사의 성공지능 교수효능감과 집단적 교수효능감 분석 [the analysis of teaching efficacy for successful intelligence and collective teacher efficacy to STEAM]. Secondary Education Research, 62(1), 93-116.

Lee, J.-K, Lee, T.-K., Shin, S., Chung, D.-H., \& Oh, S.-W., \& (2013). 중등학생들이 생각하는 융합인재에 대한 이미지 유형 탐색 [Exploring the image types of secondary school students' perception about the talented person in convergence]. Journal of the Korean Association for Research in Science Education, 33(7), 1486-1509. https://doi.org/10.14697/ jkase.2013.33.7.1486

Lee, J., Lee, T., \& Ha, M. (2013). 교사들의 아이디어 융합과정에서 나타나는 교역지 대의 진화과정 탐색: 자율적 학습공 동체 'STEAM 교사 연구회' 사례 연구 [Exploring the evolution patterns of trading zones appearing in the convergence of teachers' ideas: The case study of a learning community of teaching volunteers 'STEAM teacher community]. Journal of the Korean Association for Research in Science Education, 33(5), 1055-1086.

Lee, J.-M., \& Shin, Y.-J. (2014). 융합인재교육 (STEAM) 수업에서 초등교사들이 격는 어려움 분석 [An analysis of elementary school teachers' difficulties in the STEAM class]. Journal of Korean Elementany Science Education, 33(4), 588-596.

Lee, H. N., Son, D. I., Kwon, H. S., Park, K. S., Han, I. K., Jung, H. I., et al. (2012). 통합 STEM 교육에 대한 중등 교사의 인식과 요구 [Secondary teachers' perceptions and needs analysis on integrative STEM education]. Journal of the Korean Association for Research in Science Education, 32(1), 30-45.

Lim, S., Chae, D., Kim, E., Hyun, D., Kim, O., \& Han, J. (2014). 융합인재교육(STEAM)의 현장적용에 대한 초등 교사들의 인식 조사 [Students' perceptions after application of a subject substitute STEAM program-focusing on energy unit in 6th grade curriculum]. Journal of the Korean Society of Earth Science Education, 7(1), 119-132.

Lynn, A. B., Moore, T. J., Johnson, C. C., \& Roehrig, G. H. (2016). Integrated STEM education. In C. C. Johson, E. E. Peters-Burton, \& T. J. Moore (Eds.), STEM road map: A framework for integrated STEM education (pp. 23-37). New York: Routledge.

Martin, M. O., Mullis, I. V. S., Foy, P., \& Hooper, M. (2016). TIMSS 2015 International Results in Science. http://timssandpirls.bc.edu/ timss2015/international-results/. Accessed 29 Sep 2018

McLaughlin, M. W., \& Talbert, J. E. (2001). Professional communities and the work of high school teaching. Chicago: University of Chicago Press.

Moon, D. (2015). 융합인재교육(STEAM)에 대한 교사의 관심단계와 활용수준 [Teacher's 'stages of concerns' and 'levels of use' on STEAM education]. The Journal of Korean Association of Practical Arts Education, 28(1), 35-52.

National Academy of Engineering and National Research Council. (2014). STEM integration in K-12 education: Status, prospects, and an agenda for research. Washington, DC: The National Academies Press. https://doi.org/10.17226/18612.

Nationales MINT (STEM) Forum. (2014). MINT-Bildung im Kontext ganzheitlicher Bildung [STEM-education in the context of holistic education]. Munich: Herbert Utz Verlag.

National Research Council. (2010). Standards for K-12 engineering education? Standards for K-12 engineering education? Washington, D.C.: National Academies Press. https://doi.org/10.17226/12990.

National Research Council. (2012). A framework for K-12 science education: Practices, crosscutting concepts, and Core ideas. Washington, D.C.: National Academies Press. https://doi.org/10.17226/13165.

NGSS Lead States. (2013). Next generation science standards: For States, by States. Washington, DC: The National Academies Press. 
Organization for Economic Co-operation and Development. (2013). PISA 2012 results: Ready to learn: Students' engagement, drive and self-beliefs (volume III). Paris: PISA, OECD Publishing.

Organization for Economic Co-operation and Development (2016). The OECD Learning Compass. Available at http://www.oecd.org/education/2030/. Accessed 29 Sep 2018.

Park, H., Byun, S., \& Sim, J. (2016). Teachers' perceptions and practices of STEAM education in South Korea. EURASIA Journal of Mathematics, Science \& Technology Education, 12(7), 1739-1753. https://doi.org/10.12973/eurasia.2016.1531a.

Partnership for 21 st Century Learning (2009). Framework for 21st century learning. http:/www.p21.org/our-work/p21-framework. Accessed 29 Sep 2018.

Rho, M., \& Yoo, J. (2016). 융합인재교육(STEAM) 프로그램의 과학과 정의적 영역에 대한 메타분석 [A meta-analysis on STEAM programs and science affective domains]. Journal of Educational Evaluation, 29(3), 597-617.

Sanders, M. E. (2012). Integrative stem education as best practice. In H. Middleton (Ed.), Explorations of best practice in technology, design, \& engineering education. Vol.2 (pp. 103-117). Queensland: Griffith Institute for Educational Research.

Savery, J. R. (2006). Overview of PBL: Definitions and distinctions. Interdisciplinary Journal of Problem-Based Learning, 1(1), 9-20. https://doi.org/10.7771/1541-5015.1002.

Scherr, R. E., \& Hammer, D. (2009). Student behavior and epistemological framing: Examples from collaborative active-learning activities in physics. Cognition and Instruction, 27(2), 147-174. https://doi.org/10.1080/07370000902797379.

Shin, M. (2018). 초등학교 융합인재교육(STEAM) 프로그램 효과 메타분석 [meta-analysis of the effects on the STEAM program for elementary school students]. Journal of Curriculum Integration, 12(2), 47-66.

Shin, Y. J., \& Han, S. K. (2011). 초등학교 교사들의 융합인재교육(STEAM)에 대한 인식 연구 [a study of the elementary school teachers' perception in STEAM (science, technology, engineering, arts, mathematics) education]. Elementary Science Education, 30(4), 514-523.

STEM Learning (2018). About us. https://www.stem.org.uk/. Accessed 29 Sep 2018.

The STEAM Journal (2013). Aims and Scope. https://scholarship.claremont.edu/steam/vol1/iss1/. Accessed 25 Feb 2019.

Wineburg, S., \& Grossman, P. L. (Eds.). (2000). Interdisciplinary curriculum: Challenges to implementation. New York: Teachers College Press.

Wallace, C. S., \& Kang, N.H. (2004). An investigation of experienced secondary science teachers' beliefs about inquiry: An examination of competing belief sets. Journal of Research in Science Teaching, 41(9), 936-960. https:/doi.org/10.1002/tea.20032.

\section{Publisher's Note}

Springer Nature remains neutral with regard to jurisdictional claims in published maps and institutional affiliations.

\section{Submit your manuscript to a SpringerOpen ${ }^{\circ}$ journal and benefit from:}

- Convenient online submission

- Rigorous peer review

- Open access: articles freely available online

High visibility within the field

- Retaining the copyright to your article

Submit your next manuscript at $\boldsymbol{\nabla}$ springeropen.com 